\title{
Between the Borders and Internal Control: The Evolving Character of the Nation State in a Transnationalist Pastoralist Zone: A Case Study of the Turkana of Kenya and Karamojong of Uganda
}

\author{
Olang Sana ${ }^{1}$, Adams Oloo $^{2}$ \\ ${ }^{1}$ School of Development and Strategic Studies, Maseno University, Maseno, Kenya \\ ${ }^{2}$ Department of Political Science and Public Administration, University of Nairobi, Nairobi, Kenya \\ Email: jsanaoke@yahoo.com, adams_oloo@yahoo.com, aoloo@uonbic.ac.ke
}

How to cite this paper: Sana, O. and Oloo, A. (2019) Between the Borders and Internal Control: The Evolving Character of the Nation State in a Transnationalist Pastoralist Zone: A Case Study of the Turkana of Kenya and Karamojong of Uganda. Open Access Library Journal, 6: e5506.

https://doi.org/10.4236/oalib.1105506

Received: May 27, 2019

Accepted: July 13, 2019

Published: July 16, 2019

Copyright $\odot 2019$ by author(s) and Open Access Library Inc.

This work is licensed under the Creative Commons Attribution International License (CC BY 4.0).

http://creativecommons.org/licenses/by/4.0/

\begin{abstract}
This paper sets out to analyze the impact of nation-state modernity on the pastoral Turkana and Karamojong communities of Kenya and Uganda respectively. Focusing on two defining features of a nation-state, that is, borders and internal control, the study explores how and to what extent the political and security organization of the traditional pastoral communities have been transformed as a result of the nation-state project. The paper argues that the political and security organization of the two neighboring communities has undergone minimal transformation due to weak penetration of the states in the pastoralist zone. Traditional notions of government and security are still dominant and pose a challenge to the operation of the state. At the same time, the advent of international borders has done very little to control illegal immigration across the Kenya-Uganda border. Not only are the borders lacking demarcation on the ground over a century after they are drawn on the map, in the same vain, but also large sections are not patrolled or secured by national police. Consequently, traditional concept of borders-as defined by physical features and historical memories-still govern the movement of the pastoralists in the zone. While Kenya and Uganda have separately imposed coercive and co-optation activities on the pastoralists in a bid to subdue the traditional notions of government and security, these measures have yielded minimal results on the ground. At best, the state-led security policies and activities have sparked off tension and resistance, leading to widespread conflict, violence and instability in the zone. The obtaining chaotic situation raises fundamental questions about the capacity of the adjoining state to police their
\end{abstract}


borders and to exercise internal control over their respective populations as widely presumed by the Realist School. The paper concludes that the nation-state still exists as an unaccomplished project in the zone, at least from the standpoint of borders and internal control.

\section{Subject Areas}

Politics

\section{Keywords}

Nation-State, International Borders, Security

\section{Introduction}

International borders and internal control are the hallmark of nationhood. Borders divide the line between one state and another hence they delineate the geographical spread of a state thereby defining the jurisdiction under which the state is permitted to exercise internal control or claim sole legitimate authority [1]. Indeed, a clearly defined territory is one of the features that mark off the state from earlier political forms such as pre-modern empires [2]. This feature of statehood is recognized by a wide range of writers from Hobbes through Engels and Weber to contemporary theorists such as Mann and Giddens. According to Anthony Giddens, "a nation-state is a political apparatus, recognized to have sovereign rights within the borders of a demarcated territorial area (italics mine)" [3].

International Relations scholarship traces the origin of the nation-state to the 1648 Treaty of Westphalia [4] that re-organized European international relations in ways that could mitigate the incessant wars-particularly the 100 Years War-and achieve durable peace [5]. Although states existed in some form before 1648, the Peace of Westphalia was generally acknowledged as the moment in Western World when the nation state became the primary actor in the international system [6]. The modern-nation state is presumed to have a well-defined territory over which it exercises monopoly over legitimate violence and is therefore in full control of the domestic sphere. Sovereignty means the state has absolute supreme authority within the boundary of its territory: it can make laws, shape foreign policy, and make its own actions without the approval of a higher authority [7]. As Nui Geping reminds us "only the state can resort to violence legitimately, and all other associations or individuals within the territory have no right to use force without the authority of state" [8]. Law and policymaking are centrally located within a state and final power rests with the central government, which makes the laws and practices uniform across the country [9]. In other words, the modern state has a "right" to monopolize exercise of power with respect to territory and citizens [10].

IR theory assumes the existence of congruency between state territory and ci- 
tizenry. While this is not the case in practice in majority of modern-day political units, it is taken as a given that all permanent residents of the state should be citizens, and all citizens should reside within the state. Consequently, citizens are not allowed to cross the externally bounded political space without immigration permit or official authorization [11].

Although the nation-state is still evolving, its formulation has today become the dominant form of political organization as well as the primary unit of analysis in international relations at least from a realist standpoint [12]. Indeed, there is a growing global hegemony of nation-state template as evidenced by the fact that the world is today divided into some 194 nation-states [13].

The nation-state formulation emerged outside Western Europe through colonialism and occupation of foreign lands in Africa, Asia, North America, Australia and New Zealand. Independence movements of the late 1950s set majority of these colonies free by 1960s. The newly independent states inherited from the colonial government borders, citizens, governmental authority and sovereignty. Thus, the post-colonial construct acquired attributes of the nation-state even though they were at different levels of accomplishment [14].

This paper analyses the impact of the advent and operation of the nation-state on the political and security organization of local pastoral communities. The analysis is limited to only two features of the nation-state, that is, international borders and internal control. The critical questions that this paper seeks to address are twofold: 1) Has the advent and operation of international borders (which have lasted about a century in the study zone) affected the security and political organization of the pastoral communities in any significant way? 2) To what extent have efforts by the colonial and post-colonial states to exercise control over the traditional communities been successful? How and by what measure have such interventions transformed traditional notions of security and government?

The study is based on the Kenya-Uganda border zone that is inhabited by the Turkana of North Western Kenya and the Karamojong of North-eastern Uganda. These communities share traditional and international border which spreads over an area of approximately 124,000 square kilometers. While the two nation-states are new entrants in this region, the local communities have resided here for centuries before colonialism and after [15]. The Turkana and Karamojong also share common socio-economic and cultural characteristics that are relevant to this study.

The paper is organized in four sections. The first section describes the socio-cultural and political organization of the two neighboring pastoral communities as well as their notions and perceptions of security. An attempt has been made in this section to explore societal perception of security and how it departs from security policies of the modern state. The second section explains how Kenya-Uganda international borders were established by the colonial governments, issues that were put into consideration and the challenges encountered. 
Section three shows how the colonial and post-colonial states have attempted to stamp their authority in the zone through internal control and border policing. The main findings of the study are presented in section four which lays out change and continuities in respect to the political and security organization of the Turkana and Karamojong following the advent of borders and consequent establishment of the nation-state project.

\section{The Political and Security Organization of the Turkana and Karamojong}

The Turkana and Karamojong share fundamental aspects of social, economic and political organization that in turn forms the security substructure of the society. The economy of the communities in the region is predominantly nomadic pastoralism due to the prevailing arid climatic conditions. Cattle are at the center of local security system and are the subject of threats, defense, and offense. Consequently, security is defined and configured primarily in relation to the protection of livestock around which the livelihood of the community revolves. This can be best confirmed by exploring the meaning and configuration of security in local dialect.

Among the Turkana, security (ekisil) refers to a situation of "certainty", that is, when the community is sure that the enemy is not likely to attack, kill or drive away livestock any time soon. Ekisil leads to peace (ajokis) or security (ejok), a situation which only obtains after the Turkana have entered a pact or a solemn agreement with the rival neighbors never to raid each other for cattle again. Such agreements are usually marked by a traditional ceremony presided over by elders. Livestock of the rival communities can thereafter share watering points and pasture which lie on either side of the border.

The opposite of ekisil in Turkana is ekibaket which is a situation of actual armed conflict or war between the local community and the traditional enemy. Ekibaket obtains when the enemy has either attacked, killed and driven away livestock or is about to raid. This condition is marked with much impatience, restlessness and uncertainty because the attacked community mobilizes to revenge and recover the stolen livestock while the attacker works restlessly to ward off counter-attack or limit damages likely to arise from the counter-raid. Among the Turkana, war (nyejie) is a total breakdown of peace which only results from cattle raids and competition with neighbors over water and pasture.

The Karamojong have a wider construction of security. According to the Bokora sub-clan, the community is at peace (also ekisil) in the absence of actual or eminent threats of attack from a rival community and also when the community enjoys safety from natural calamities. Consequently, the Karamojong are most secure when there is plenty of pasture and water for their livestock, and when the animals are healthy and safe from disease. The simultaneous increase in the number of livestock through husbandry or cattle raids and general wellbeing of the society through intra and inter-tribal marriages are also indicators of securi- 
ty. The opposite or lack of these factors implies insecurity.

In all the above cases, security referent objects are members of community as a whole, livestock and territory. The lands inhabited by the Turkana and Karamojong are communal and are held in trust by the groups themselves. The communities have a strong feeling of belonging not only to their group but also possession and/or dominion over their territory. Hence, survival of the community depends on their capacity to access all or large portions of their territories which they use for grazing, hunting, and performance of cultural activities. Land is also crucial for sedentary agriculture and serves as the source of herbal medicine which cures human and livestock diseases. Access to pasture and water points is therefore open to all community members at any time. However, elders may regulate the use of grazing land and water so as to avoid conflicts and resource depletion.

The traditional concept of territory encompasses land that the Turkana and Karamojong presently occupy as a community as well as those that may lie outside their jurisdiction but to which they lay claim because they once grazed or organized a cultural activity there according to oral narratives passed down from one generation to another. The boundaries of a territory in these communities are marked by physical features such as hills, mountainous ranges, rivers, lakes, valleys, and rocks. Beyond these features dwell the neighbors often perceived as enemy. And since the communities enjoy sovereignty over their land and territory, neighbors may only access water and forage for their livestock in neighbour's territory through negotiated agreements initiated by elders. However, herders may cross forcibly into the territory of a neighboring community during periods of water scarcity. Such unsanctioned incursions are fiercely resisted as they undermine the sovereignty and security of the invaded community. Therefore, the territory is an object of protection to conserve scarce water and forage reserves on which the livelihood of animals depend.

Apart from territory, the community is also a key focus for protection because it provides both the philosophy for the rationalization of the individual's existence and the theatre for self-actualization. The individual lives for himself and also for the community and each person has a role in the protection of the community and its values irrespective of gender, social status and age-group. Under the prevailing philosophy of "group security", death of a member or loss of livestock to a rival group increases the vulnerability of the community to enemy and is strongly resented. Intra-communal violence is culturally intolerable because it weakens the community and exposes it to external threats.

The harsh arid and semi-arid climate characterized by scarcity of water and pasture have made it imperative for the Turkana and Karamojong to place their survival almost entirely upon themselves. Community "self-help" strategies have evolved and developed under a strong network of traditional leadership structures, authority and institutions in which nearly every adult member of the society plays a role. The highest source of authority in each community is the 
council of elders. The elders (ekaskou in Turkana) derive their authority not only from their age but also their duty and capacity to organize the people into age-categories each of which bears a chain of responsibility. The elders are also considered to have divine authority or at least to be closely linked to divine authority. It is the responsibility of the elders to maintain good relations with the deity for the protection of the community and their cattle. The consequence of violating elders' authority is punishment inflicted by younger obedient men (called ameto), or by deity ( $A k u j)$, leading to misfortune, or death of the disobedient member of the community. The elders distribute political functions to the younger generation by allocating the responsibility of grazing; defending the community, its livestock, and grazing zones; and raiding neighbors to augment cattle. It is also the responsibility of the elders to initiate and negotiate peace pacts with neighbors as well as access to water and pasture during periods of scarcity or as the situation may from time to time demand. While elders' political leadership roles is not hereditary, those who possess large heads of cattle and command both oratory and negotiation skills may emerge prominent and exercise leadership in sections of territory.

Below the elders are the diviners (ngikatamak) who provide spiritual protection to the pastoral communities and their animals. Unlike the elders, the institution of ngikatamak is hereditary. Through dreams or by studying the intestines of a slaughtered cow, the ngikatamak have a rare spiritual power to foretell misfortunes especially an impending calamity, or other dangers to the community and its livestock. The ngikatamak also blesses raids, forecasts the outcome of a planned raid or military offensive launched by the community against rivals, and foresees threats to the livestock including drought and disease outbreak. More importantly, the ngikatamak provides the community with options for remedying impending security threats. Such remedies might include relocating to safer grounds or slaughtering a bull in a ceremony to ward off the misfortune. The spiritual leader may summon the elders and their councils (akiriket) any time of the day to reveal the threat to the community. The akiriket rarely goes against the counsels of the ngikatamak. Likewise, the ngikatamak seldom misuse their divine power to undermine political authority the elders, or for material gain.

The social responsibility of tending livestock rests with young men (often aged between 17 and 35) who have a duty to ensure that livestocks are well watered and protected in the face of challenges from natural environment and neighboring communities. The task of tending livestock invariably keeps the youth away from home for long durations. Such excursions are often fraught with peril since finding the best watering and grazing resources brings them into conflict with neighboring pastoral communities that compete for the same source of forage. The youth are prepared for their challenging role in the community through rigorous socialization that begins in childhood. Parents and adults inculcate in the minds of the growing youth the virtues of skillful herd management and proving oneself courageous under difficult circumstances. Through various social agen- 
cies, the youth grow into adulthood absorbing into their subconscious highly cherished community value of heroism, courage, endurance, "manliness", and herding skills. The images of historical enemies are constantly replayed and made to hammer into the minds of the young thus they take it as a social duty to defend their family and community. Protecting the livestock is more valued than the lives of herders because the community hails him as a hero a man whose livestock have been looted after he has been killed while defending them. If, however a herder survives the fight but loses livestock, he risks being despised as coward. Thus, the youth grow up courageous and oriented towards adventure, in a social environment that nurtures revenge and violence against traditional enemies. A parent feels very insecure if his/her sons lack the courage without which they cannot protect family livestock. In sum the socialization of children is such that they grow into adulthood, shaped and conditioned by customs and expressions idealizing qualities associated with involvement in cattle rustling.

It is against this background of functional tribal government replete with authority structure and strong attachment to traditional notions of security that the modern state was superimposed through colonialism and subsequently continued by the Kenyan and Ugandan indigenous political elites at independence. The superimposition of the state was bound to meet resistance as will be discussed in the last section. The next section now shows how the colonial administration drew the international border that separates Kenya and Uganda (and by extension, the Turkana and Karamojong) as well as the considerations that influenced the conduct of this exercise.

\section{The Advent of Kenya-Uganda International Borders}

The establishment of colonial borders at the close of $19^{\text {th }}$ century was one of the most remarkable early effects of colonization in East Africa. The Kenya-Uganda boundary is approximately 580 miles long. From the tripoint with Tanzania, it was drawn to extend northward through Lake Victoria for 86 miles. Except for about 94 miles between the Bukwa and Kanamuton rivers, the remainder of the boundary was demarcated by pillars and rivers [16]. The British Foreign Office transferred on April 1, 1902, the then Eastern Province of the Uganda Protectorate leading to the extension of the Western boundaries of the East African Protectorate into Uganda [17]. The province was delimited on the west by the present Kenya-Uganda boundary, on the North by the Suam or Turkwel River, on the East by the eastern escarpment of the Rift Valley, and on the South Lake Victoria [18].

The colonial officers in Kenya and Uganda were particularly concerned about leaving the pastoral communities affected by the borders (the Turkana, Karamojong and Pokot) under one administration. In his letter to the Secretary of State for Colonies in July 1919, Edward Northey, the Governor of Kenya raised serious concerns about the portion of the Kenya-Uganda border occupied by the Suk (Pokot), Turkana, and the Karamojong. The boundary, in his words was 
"unsatisfactory because it cuts Northern and Southern Turkana into two and does not satisfactorily define the borders of the Turkana, Suk and Karamoja tribes...the boundary should, if possible leave the whole of any one of these tribes under one administration" [19].

It was later agreed between Governor Northey and Robert Coryndon, the Governor of Uganda, that the Turkana and Pokot be placed under the administration of East African Protectorate (EAP) while leaving the whole of Karamoja in Uganda. First, it was argued that the EAP was more convenient in managing issues relating to the Turkana and Suk because for a long time it had been closely connected with them. Secondly, those areas of Southern Turkana and Suk territories were in the vicinity of Trans-Nzoia, an area that was already under white settlement and controlled from Nairobi.

To the British officials in the two protectorates, the main purpose of the boundary was not only to ensure effective British administration of their respective areas, but also to control the people's primitive way of life. In particular, the British officials wanted a clear boundary which could be identified easily both on the map and on the ground, and to keep the tribes and their livestock firmly behind the line [20]. Indeed, the colonial (and even post-colonial) governments viewed the pastoralist way of life as chaotic, economically unproductive, and environmentally destructive. Imposition of boundaries was therefore a means of settling them. By implication, the boundary policy demanded that all people crossing it had to get official permit to do so from government officials manning it and at designated boundary control points.

In September 1919, the Secretary of State for Colonies gave a formal approval to the proposed boundary adjustments between the two protectorates and the two governors organized for the demarcation of the new boundary. In 1926, further territorial transfers from Uganda to Kenya were made involving Rudolf Province and the Pokot territory, by an Order in Council [21]. In the Schedule annexed to the Order, Kenya-Uganda boundary was delimited in three sectors from south to north, that is, boundary from $1^{\circ}$ south latitude, through Lake Victoria to the Mouth of the SioRiver; boundary from the Mouth of the Sio River to the summit of Mount Elgon and; boundary from the summit of Mount Elgon to Mount Zulia, on the boundary of the Anglo-Egyptian Sudan. The problem of protection of the Turkana now fell squarely on the Kenya colony following the cession of Rudolf Province to the East African Protectorate.

Uganda and Kenya gained independence in 1962 and 1963 respectively. The drawing of the boundaries on the map and practical attempts to demarcate borders on the ground gave the two countries a new status as international states. This move would have far-reaching consequences on the political and security organization of the indigenous communities that lived in the zone. The fact that these boundaries involved the definition of new areas to be occupied by each community in terms of geographical demarcation no doubt constituted a barrier to the movement and economic activities of the two communities [22]. 


\section{The Institutionalization of Government Authority in the Pastoralist Zone}

\subsection{Internal Control and Border Policing during the Colonial Times}

Boundary creation by the colonial administration was not accompanied by an equal measure to demarcate and police them. Consequently, borders did not immediately stop the pastoralists' movements neither did they control the traditional culture of cattle raids between the Turkana and Karamojong. However, the borders did impose international responsibility on Kenya and Uganda to administer the Turkana and the Karamojong respectively, who now fell squarely within their territorial jurisdiction. The main concern of the colonial administration at the very outset was not so much to police the borders but to instill some form of control among these communities as would make them settled, abandon inter-tribal raids, and dispossess them of firearms which were already in circulation in the zone. It became apparent to the colonial administration that undertaking such a demanding task required a significant amount of resources and trained military personnel both of which were in short supply during the early periods of colonial enterprise. Stamping governmental authority in the zone, therefore, posed a great challenge to the administration not just because of the long distance the personnel had to travel from the headquarters to the zone but also due to rampant insecurity and semi-arid and hostile climatic conditions.

Compounded by its agricultural unproductivity, the colonial administration was at the initial stage persuaded to leave the pastoral communities outside their direct control [23]. However, the fear of Menelik II encroaching into British territory forced a rush northwards so as to pre-empt the invasion. The British's main concern was to keep away the well-armed Ethiopians whom they viewed as raiders and poachers, and to ensure that their pastoralist subjects were protected [24]. A military station was opened at Lokiriama (Turkana) in 1916 to officially establish British presence in the area. Two years later, the British launched a series of pacification campaigns in Turkana, the most famous being the Labur Patrol of 1918 in order to control the community's habit of raiding its Pokot neighbors to the South. According to John Lamphear, the British killed thousands of Turkana warriors during the Patrol and seized over 250,000 animals [25]. Thereafter, civil administration in Turkana was introduced marked with the opening of administration blocks in Kakuma and Lodwar in 1919, Lokitang in 1928 and Todenyang in 1929. Lodwar became Turkana district headquarters in 1932 [26].

The efforts by the colonial administration to stamp government presence in Turkana and to stop intertribal raids and migration southwards met stiff resistance because they were launched at a time when the community still owed strong tribal allegiance to elders, diviners, and warlike leaders, who commanded a lot of respect. The British employed coercive means to redirect loyalty to the colonial government by arresting and confining such influential leaders. First, 
Koletiang-an influential leader from Turkana South-was imprisoned in 1911 for leading resistance against poll tax. In 1926, Labon Kokei was arrested and detained. In the same year, Lowalel-one of the most powerful Turkana spiritual leaders-was arrested and deported to Kitale where he died and was buried. Such coercive strategies-accompanied by sporadic military campaigns in the Turkana-instilled in the community a sense of fear and respect, leading to their lukewarm submission to colonial authority.

Like Turkana, Karamoja remained outside the effective control of the colonial administration for several years after $t$ Uganda was declared a British protectorate in 1894. Being a semi-arid region, Karamoja did not offer the attraction that encouraged the colonies to produce cash crops like cotton and coffee, which were meant to feed the industries back home in England [27]. However, rumors about gun-running, ivory trade, territorial incursions by Ethiopian warlords and private armies operating on the Turkana-Sudan-Ethiopia border as early as 1910 proved a major challenge to the British colonial administration as it introduced difficulties in the maintenance of law and order in the Protectorate [28]. The British therefore decided to pacify the Karamojong before establishing administrative control over the territory.

The colonial government extended its military presence in Karamoja in 1911 through the Northern Patrol under the command of Captain Tufrell who pacified the area and established a military administrative outpost at Koputh. He also appointed colonial Chiefs to assist the military administration of the district [29]. In the same year, the Protectorate Government declared Karamoja a "closed district", allowing only one opening into the area through one border post at Iriri in Bagisu District. No one was allowed to enter Karamoja except through the border post anda foreigner had to possess a valid pass obtained from the colonial office in Entebbe. The notice at Iriri border read:

"You are now entering Karamoja, a closed district. No one may enter without an Outlying District Permit” [30].

In 1921, a new administration was established in Karamoja under B.A. Warner and G.H.M Lamb with firm instruction to put in place rudimentary civil administration in the area. As in other parts of the country, the new administration attempted to generate revenue to administer the territory. It also prohibited pastoral migration on grounds that it was primitive. The imposition of these policies sparked anti-colonial violence against the regime and its local agents. In 1923, the people of Nabilatuk ((South Karamoja) murdered one of the colonial Chiefs-Achia-for collaborating with colonial administration to implement bad policies. The government responded to the challenge to its legitimacy by employing collective punishment: cattle were seized, settlements were destroyed, and adult members of the area were fined in an effort to force the people of South Karamoja to hand over the person, who had murdered Achia. When the murderers were not identified, the Colonial Administration randomly picked three detainees. On $14^{\text {th }}$ February, 1924, the three suspects were hanged at Nabilatuk before a gathering of inhabitants surrounded by the King's African Rifles 
detachment [31]. Recourse to coercion gradually introduced fear in the community and discouraged the Karamojong from openly challenging the legitimacy of the colonial state and persons in position of authority.

From the foregoing, it is evident that the Turkana and Karamojong encountered a superior, advanced and heavy-handed military force organized under and commanded by the Colonial Administration. The expeditions and pacification campaigns launched by the colonial state during this period were not comparable to the military might of their neighbors. The communities therefore began to recognize the authority-albeit hesitantly—of government security forces and as well as government administration officers that were deployed to stamp government authority and presence amongst them. This early period witnessed the slow decline in the power of the traditional authority which arose with the establishment of new leadership institutions such as colonial Chiefs and the Headmen who were recruited from the local communities. In this way the traditional elders were now sidelined.

While the declared purpose of the borders was to keep each community firmly on its side, the persistent cross border movements between the two communities did not immediately capture the attention of the colonial government. In fact, the colonial administration was more concerned about controlling the Turkana and Karamojong migration southwards to areas where commercial farms were already established than across the borders. Also, border violations were tolerable because the two neighboring states were under British rule and therefore local administrative officers could negotiate an amicable solution to the menace. The burden of intensifying internal control and border policing would pass on to independent Kenya and Uganda.

\subsection{Internal Control and Border Policing in the Post-Independence Period in Kenya and Uganda}

Kenya and Uganda maintained some colonial policies in their respective relationships with the Turkana and Karamojong especially during the first three decades after independence. The turn of the millennium has witnessed increased state presence in Turkana and Karamoja regions of Kenya and Uganda respectively. In particular, Kenya has pursued polices that are geared towards containing cattle-rustling between the Turkana and its cross-border neighbors through cattle-branding, whose aim is, in part, to enable easy identification of Turkana livestock [32]. Uganda-under Museveni administration-has also been involved in cattle branding for ease of identification of alien cattle stolen from neighbors [33]. Cattle branding in Karamoja has been complemented by sporadic cordon-and-search exercises aimed at recovering stolen animals especially those that bear alien branding labels. The army arrests the culprits and charge them with theft in the land (within Uganda) where the animal was stolen-the goal being to intimidate them and to discourage any would be raiders.

Apart from cattle branding, the Uganda People's Defense Force (UPDF) have 
been involved in grazing Karamojong cattle in a move aimed at forestalling cattle rustling both within Karamoja and across Uganda's border with Kenya and South Sudan [34]. Under this arrangement, cattle are kept in protected kraals at night but the army assumes the responsibility of grazing them during the day. The project ran from 2004 to 2008 but was subsequently abandoned in 2009 after the government established that the idle Karamojong youth had time to plan and execute more raids. Cattle have since reverted to the care of owners but UPDF still secures them in the field, especially to ward off day-time raids from cross-border neighbors.

Kenya incorporated Turkana elders and traditional authorities in Peace Committees (PCs) whose primary aim is to cultivate a culture of peace by networking with key stakeholders who work together to enhance harmonious relationships within and among communities [35]. The government has used PCs as a forum for launching initiatives in Turkana such as the eradication of illicit firearms and general security surveillance. Further, the Kenyan government has since 2011 supplied kraals in Turkana with radio call gadgets and mobile phones for emergency alerts in case a raid occurs. Some police stations are established in the kraals and government administration officers (especially the Chief) have informers operating from within. Through this strategy, the government has been able to obtain intelligence information about planned raids and to gauge the acceptance of government surveillance policies and programs in the community.

Both Kenya and Uganda have incorporated vigilantes in state security surveillance operations. Beginning 1992, Uganda recruited and deployed local defense units (LDUs) to step up security operations in Karamoja area and specifically to control cattle rustling. Under this arrangement, the Karamojong warriors would lead the chase for the stolen livestock as UPDF follows closely behind [36]. This strategy would help to minimize casualty for the UPDF army personnel in the likely event the raiders fight back to repulse their pursuers. Recruits into the force were recognized youth leaders in the community who owned guns [37]. The increasing success of LDUs in security management compared to UPDF influenced the government to expand their mandate to include providing escort services to government officials whenever they needed to go into an area where there is a high potential for violence or protest especially disarmament talks with the local populace. Through such strategy, the Ugandan government has been able to reach many parts of Karamoja where the very presence of government officials would otherwise ignite suspicion and violence. The vigilante program ran for four years (1992-1996) after which it was suspended and replaced with a paramilitary force called the Uganda Anti-Stock Theft Unit.

Like Karamoja, Kenya has recruited and deployed Kenya Police Reservists (KPRs) as a critical force in the containment of security crisis in Turkana. KPR is composed of young energetic local warriors who are recruited into the force because they possess fighting and cattle raiding skills. The reservists provide secu- 
rity for kraals and caravans in rural areas and are relied on heavily to deter cross-border raids. Since 2010, KPRs have moved into urban areas such as Lodwar, Lokichoggio and Kakuma where they perform duties usually designated to police including undertaking arrests. KPRs are also paid to guard schools, churches, businesses, and private organizations such as NGOs operating in Turkana, particularly those with offices outside urban centers. In some areas they act as spies for the police and General Service Unit.

KPRs are the most visible organized security force in the community. The officers have good mastery of the local areas where they operate which helps them to predict and pre-empt raids. Further, they are capable of navigating and traversing difficult terrain while pursuing stolen livestock and they are highly motivated despite lack of pay. Indeed, the reservists are very committed to duty since they protect their own cattle. Therefore, they earn praise and rewards from the community whenever they succeed in averting a raid and this gives them a sense of pride, self-esteem and the resolve to take risk.

Another far-reaching security surveillance operation in Turkana and Karamoja has been disarmament. Both governments employed forceful disarmament almost in the same period as strategy for ending cattle rustling and the activities of armed warrior groups who cause internal and cross border insecurity including threats to government security forces. In Turkana, the Kenya government considers the possession of illicit firearms by civilians unacceptable on grounds that "only the state has the monopoly of use of force" [38]. The government is also convinced that disarmament is a prerequisite for the introduction of alternative livelihood that would reduce over-dependence on livestock. Likewise, the Ugandan government has embarked on disarmament in Karamoja to stop criminals from among the armed Karamojong from terrorizing their neighbors within Uganda and across the border [39].

Numerous government-led disarmament initiatives of varying scale have been launched in Karamoja. The January 2001 disarmament campaign involved persuading the warriors to voluntarily hand over guns in return for iron sheets of corrugated iron roofing materials and certificates noting the surrender of weapons by an individual or family. Phase I yielded a dismal 6500 guns by January 2002 and 9763 by mid-September same year. In May 2006, the UPDF introduced "Cordon and Search Operation (CSO)" which were designed to remove small arms directly from communities. Under this operation, communities were effectively occupied by the military until the UPDF were satisfied with the number of guns that had been surrendered. Over time, these operations changed from targeting villages, by cordoning off and searching, to targeting households by using more violent means [40]. By 2008, the UPDF announced they had recovered only 30,000 guns from the region [41]. Forcible disarmament stopped following the creation of peace committees by the district security teams. However, the Ugandan government has maintained constant surveillance operation in the region through UPDF and the police. 
In Kenya, the first disarmament phase codenamed Operation Dumisha Amani (maintain peace) I commenced in 2000. A voluntary phase ran between May 2005 and February 2006. Under this phase, those with illicit weapons were encouraged to surrender them at designated points. However, Dumisha Amani I did not yield sufficient guns, hence it was followed by Operation Okota ((collect) which ran from April to May 2006 [42]. This phase involved coercive measures targeting the warriors and households although voluntary surrender was allowed.

In 2010, the government launched Operation Dumisha Amani II as a continuation of the previous disarmament and development program designed to recover 50,000 arms from northern Kenya, including from the Turkana. As of August 2010 the operation had netted 1201 firearms, 1665 rounds of ammunition and 201 stolen livestock [43]. The government was not impressed by the dismal number of guns collected under Operation Dumisha Amani II considering the target it had set. While disarmament continues in Turkana as a matter of government policy, its failure to yield the desired result has forced the Kenyan government to rethink the approach. The government has since embarked on other community-based strategies to discourage gun culture. Such strategies include public awareness campaigns in which communities get educated through local forums organized by administration officers; appeals by local politicians and civil society organizations on the need to give up weapons as a precondition to bolstering security and restoring law and order; rolling out community safety initiatives under arms control campaign and; initiating voluntary surrender of illicit arms programs in return for immunity from prosecution.

The above internal security measures by Kenya and Uganda have been complimented by border policing and surveillance so as to contain the Turkana and Karamojong on their respective sides of the border. Indeed, regional states have made some progress towards establishing international borders. The Kenya government shifted its border post from Lokichhiogio to Nadapal (which lies $30 \mathrm{Km}$ northwards along the Red Line) in 2009 to defend its territorial integrity and to contain insecurity threats from the Toposa community of South Sudan [44]. By so doing, Kenya aimed to control the Toposa movement southwards and Turkana movement northwards. The Government of South Sudan also established a border post and an immigration office at Nadapal in 2011 to boost security. These border posts serve as official entry and exit points for immigrants. However, Kenya's North-western border with Uganda has not been demarcated and there are so far no plans to do so. Instead, escarpments and ranges still serve as territorial boundaries separating the two countries. The Kenya-Uganda border also lacks policing. By June 2012, Lokiriama District, which is located 10 kilometers on the Kenyan side of the border, had only eight police officers. Although the number of security personnel in the station was subsequently increased to 15 in 2015, these officers are still unequal to the task of averting cross-border threats emanating from the Karamojong warriors, who attack in large numbers 
and with sophisticated weapons. After Lokiriama, the vast corridor up to the Northern tip of Kenya/Uganda/Sudan border measuring about $200 \mathrm{kms}$ has no police post. This means that whenever any form of cross border aggression occurs, it takes hours and even days before Kenyan security personnel respond.

\section{Implication of Government Policies on the Political and Security Organization of the Local Communities}

The intensification of government security surveillance activities in Turkana and Karamoja has had some effect on the societal modes of political and security organization. The involvement of UPDF in grazing Karamojong livestock in the field, an activity which is traditionally assigned to the youth and warriors, has displaced the youth who now have little role to play in the community. It has also fundamentally disrupted the full operation of the society as a unit where everyone has a role to play and strives for self-actualization. Whereas such an exercise might be very rational from the government's standpoint, Karamojong households would still not entrust the security of their livestock under the care of "foreigners". Elders maintain that Karamojong cattle are better off under their own care. While they graze, their sons know where good pasture and water lie and they can identify sick cows and either treat or isolate them for specialized care. They know how many days are left before a pregnant cow brings forth a calf so they prepare the right herbal medicine for the calf and its mother. The cows know their owners, and each family knows their herds. But UPDF know nothing about livestock.

The very admission by Uganda that the involvement of UPDF in grazing Karamojong livestock left the youth idle and led them to cattle raiding confirms that this form of security surveillance has proved counterproductive in managing security in Karamoja.

The recruitment of youth to defend the community under Kenya Police Reservists (Turkana) and Local Defense Units (LDU) has disorganized traditional security management operations of each community. As discussed in the previous section, traditional security operations were secretive and inspired by the need to defend the community, livestock and territory without expectations of financial reward. By keeping KPRs and LDUs behind the police and UPDF respectively, the involvement of the youth in this enterprise is a strategy by the government to co-opt, emasculate, confuse and then render irrelevant the youth whose martial courage and skills pose a challenge to smooth penetration of the state in the pastoralist zone. Studies conducted in the recent past show that KPRs and LDUs have become unpopular in Turkana and Karamoja respectively because recruits believe they have higher status than their colleagues who did not join the force. Some act as police officers and have misused their army uniforms and firearms to harass community members and even commit crime both in the village and urban centers. Despite government promise to put KPR on pay, some have not earned a salary for over five years. Consequently, the temptation to 
misuse their guns and privileged positions to solicit for bribes and to commit crime has risen. Some have even sold or exchanged their guns and ammunitions for cattle before quitting the service.

Further, Turkana community leaders have complained that KPRs use the firearm to harass or kill innocent community members as they are not trained on police work. And since they are not provided with uniform and other identity documents, it has become difficult to distinguish a KPR officer from any other ngoroko (thug). In such circumstances, they have become a source of insecurity rather than a solution. General lack of accountability, unclear recordkeeping, and poor supervision has raised suspicion that KPR are not under government control.

While KPRs and LDUs are strategies by both Kenya and Uganda to withdraw the youth from their routine security management obligations to their communities, peace committees have served the purpose of helping the government co-opt the elders to serve the state. But despite government efforts to re-organise peace committees, they still function like the traditional Turkana council of elders. The only variation is that unlike in the past, these meetings are regularly attended by the Chief or his assistant. Eelders who sit in the DPCs believe they have answers to all problems affecting Turkana community and they have demanded that traditional security management institutions-especially the diviners-be incorporated in these forums. Indeed, cattle rustling operations would be unsuccessful without the blessings of the diviners. Yet, the government prefers to ignore them as irrelevant. The attempt by the Kenya government to incorporate influential elders in peace committees and to exclude the diviners is a strategy to render the latter completely irrelevant in the security organization of the modern state. While some diviners have maintained their spiritual leadership roles in blessing cattle raids, their power and influence in security management is generally on the decline.

Disarmament has led to unintended consequences. In Turkana and Karamoja, the exercise has led to violent conflicts between the state security personnel and the warriors. The conflict is sustained by divergent perceptions of security held by the state on one hand and the local communities on the other. Whereas the government security agencies are under pressure to enforce the modern forms of law and order which includes monopolizing coercive force, the local communities still regard self and livestock protection as their traditional obligation which they cannot relegate to the state. Consequently, the warriors have maintained a gun-culture so as to survive in hostile environment where self-help is the tradition.

Both governments subjected the warriors to torture, humiliation and inhuman treatment during forceful disarmament in Turkana and Karamoja. These transgressions have led to widespread perception that the disarmament is a form of government punishment to nomadic communities. Arising from such feelings, the Turkana and Karamoja warriors organized revenge attacks against the Kenya 
Army and UPDF in order to secure their livestock and firearms. In a number of instances, the warriors have either hurt or killed government security personnel involved in disarmament operations or those deployed to enforce the law without the accompaniment of local warriors. State security officers have therefore been included among security threats to the community against which to organize for protection and defense. Further, disarmament has left large areas of Turkana and Karamoja vulnerable to attacks from internal and cross-border cattle rustlers. Consequently, there has been aggressive re-armament in the forcefully disarmed villages. This move is a clear confirmation that Kenya and Uganda initiated disarmament at a time when factors that drive the demand for firearms in the zone had not been fully addressed. The chaos, movement and destruction associated with disarmament have also sparked off a wave of criminality hitherto unknown to the Turkana and the Karamojong. Although urban areas of Moroto, Lodwar, Lokicchogio, Kotido, and Lokichar are relatively secure due to regular police patrols, homesteads and villages outside urban areas have been left vulnerable to attacks from thugs and gangs who steal property, food reserves (including food aid), and sometimes rape and murder their victims. The criminals are youths who have been left without livestock either due to confiscation by the military or as a result of raids. The criminals feel they have lost everything of value in life so they are revenging on the society.

The physical removal of guns from the Turkana and Karamojong warriors through disarmament has failed to suppress the mental attitudes towards firearms. The resolve to continue to hold onto a gun in these communities have only increased, and so has indulgence in raiding. The majority of the warriors have not been "mentally" disarmed partly due to strong socialization process during which the community inculcates attitudes and ideologies of manliness based on brute physical strength and fearlessness. This world view is still so strong among the youth that the affected warriors say disarmament has made them "women" because they can no longer perform their cultural obligation of protecting their families and the community at large. A clan is today perceived to be insecure if it is poorly armed, that is, if it has insufficient guns and ammunitions and is, therefore, unable to effectively protect its members and livestock from attackers. This perception extends to the household and to individual levels. Rival groups within the community often organize attacks against each other to obtain guns and ammunitions alongside livestock.

Aside from internal displacement, disarmament has also provoked cross border migrations. Before the commencement the military operation in Turkana in 2006, the targeted warriors and families crossed the porous Kenya-Uganda boundary to join their relatives and allies in Uganda (the Matheniko) until it was safe to return home. When Uganda re-launched forceful disarmament in Karamoja in 2006, the Turkana pastoralists were forced to drive about 60,000 head of cattle out of Moroto to the Kenyan side of the border to avoid handing their guns over to the government. Since 1973, the Turkana have crossed over to 
Uganda and grazed their cattle with the Matheniko community (a Karamojong sub-clan) with whom they signed a peace agreement in 1973. The same tradition applies to the Matheniko. In Karamoja, a section of Dodoth herdsmen numbering about 5000 crossed the Uganda-Sudan border in 2012 and forcefully took occupation of a village in South Sudan inhabited by the Toposa so as to avoid UPDF disarmament operations. While in Toposa, the Dodoth have continued to organize cross border raids against the Turkana of Kenya and Jie of Karamoja. From these trends, we can discern a perception among the nomadic communities about "safety abroad" as evidenced by their habit of fleeing across the borders whenever there is a crisis at home. This trend is buttressed by the belief that national armies cannot pursue illegal gun holders seeking refuge in a foreign country [45].

The local communities still maintain their own perception of social justice especially the recognition that rights are collective, and not individual. The rights of an individual are still respected only insofar as they do not conflict with what is good for the community as a whole. Indeed, social justice is still strongly defined by the communal needs for survival in the hostile climatic environment in which neighbors are perceived as enemies. Traditional justice system apply especially in respect to redressing common criminal offenses in the zone such as cattle-raid and cattle-theft. In both Turkana and Karamoja, a warrior caught in the act of raiding livestock is killed on the spot if he is overpowered and the warriors engage in the exercise psychologically prepared for the consequences. Since justice is dispensed in the scene of crime, the idea of police coming in to conduct investigation after a cattle raiding incident does not make sense to the community. Equally, acquitting suspected cattle raider for lack of evidence is totally unacceptable and both communities still find it "inconceivable" to give evidence against a fellow community member in a "foreign" court. A witness who gives evidence against a fellow clansman in a law court becomes responsible for his or her suffering and may even become a target for reprisal by the clan to which the victim belongs.

The imposition of borders and attempts by Kenya and Uganda to enforce them through policing has not affected in any significant way the migratory habit of the Turkana and Karamojong on which nomadic pastoralism depends. The local communities have resisted borders as evidenced by blatant violation of immigration rules. For instance, the Turkana and the Toposa communities still cross the ill-defined Elemi Triangle with firearms to rustle cattle in a foreign territory and to forcefully gain access to water and pasture that lie across the border during dry seasons [46]. Also, the Turkana and the Toposa still lay emotional claim and attachment to areas where they once grazed or where their ancestors organized traditional ceremonies but which are currently placed under Kenyan or Sudanese territorial jurisdiction. Therefore, the local communities still recognize, accept and operate according to their traditional boundaries which were defined by frontier. In Ilemi, elders from both communities claim they have historical knowledge of boundaries based on the location of trees, rocks, and other 
physical features (some of which still survive) hence the imposition of boundaries marked by beacons still makes little sense to community members.

Going by their perceptions of what constitutes borders, the Turkana insist that Narus (25 km north of Nadapal) is their traditional boundary with the Toposa while the Toposa elders maintain their boundary with Turkana is as far down as Kakuma which lies about 100 kilometers south of Nadapal. The representatives of both communities insist that the current Nadapal border limits their grazing rights and the post has been a target of attacks by the Toposa worriers protesting its establishment. In October 2012, some armed Toposa people invaded the newly established Kenyan border post and killed 16 Kenyan military officers. A second attack occurred a week later. While the Turkana warriors have not made any attacks on the South-Sudan border post, they continue to invade Toposa cattle camps near Nadapal and further North in stark violation of South Sudan territorial integrity. The establishment of isolated police stations and army barracks along the Kenya-Uganda border has instilled some notion of (nation-state) territoriality among the Turkana and Karamojong, However, migrations patterns are still primarily determined by physical features and historical memories.

The intensification of disarmament program in Karamoja at the turn of the millennium has forced Uganda to slap a ban on unregulated immigration. While Uganda still welcomes the Turkana to graze their animals in Moroto during drought, Kampala has stressed that they must leave their guns behind before entering territory. Those who may have entered Uganda with firearms have been advised to surrender them to the nearest police station in Moroto before they continue with their grazing activities. Kenya has also emphasized that herders crossing to either side of the border for grazing purposes should notify authority in good time and should return to the county of origin at the commencement of the wet season. Although these immigration rules exist in paper, they have had very little impact on the migratory habits of the Turkana and Karamojong communities. The communities still crisscross the international borders as if they do not exist and they do so with firearms which are used to commit crime abroad. This trend persists because a large section of the Kenyan and Ugandan border is neither fenced nor patrolled by security officers. The borders exist more on the maps than on the ground.

\section{Conclusions}

This study set out to analyze the implication of the advent of the nation-state on the political and security organization of the local Turkana and Karamojong communities, a phenomenon which is largely ignored in IR discourse. By focusing on two features of the nation-state, that is, borders and internal control, the study has established that Kenya and Uganda took their initial shape through the creation of international borders during the colonial epoch. This was later followed by attempts to exercise control over the Turkana and Karamojong by stamping government authority and presence among the communities. Howev- 
er, the colonial administration imposed these measures on traditional communities who had over the year developed their own forms of government replete with political authority structures and systems of security management would enable them to survive the hostile arid and semi-arid climatic environment surrounded by the foes competing for the same resources. While the colonial government found it imprudent to concentrate resources towards the administration and control of these communities that otherwise lay in the fur-flung agriculturally unproductive zone, the independent Kenya and Uganda were compelled to impose a measure of internal control over the communities and to confine them on their respective sides of international borders.

The study has established that government security policies and activities have had some impact on political and security organization of the two neighboring communities. The role, power and significance of key security management institutions such as the youth, elders, and diviners are being undermined through government co-option. Likewise, the local communities are now under pressure to recognize and confine their operations within their respective sides of the border unless they obtain official authorization from both governments before they cross. Despite these developments, the traditional perceptions and notions of security are still strong and they pose a challenge to the smooth penetration of the state in the zone. Owing to the weak presence of the state on the ground, the traditional security management institutions and agencies are still active and their operations run counter to the policies of the state. Likewise, frontiers, physical features, historical memories, bonds and linkages still define boundaries. Consequently, attempts by Kenya and Uganda to confine the pastoralists to their respective sides of the border have yielded minimal results.

This study, therefore, concludes that despite the advent of the nation-state almost a century ago, it has not fully displaced traditional political institutions and security organizations to enable it stamp its full authority and control in the areas inhabited by the nomadic communities. But state presence in the communities through local administration and the police, army, law courts, etc. has sparked off slow, hesitant but a progressive match towards societal reconfiguration of traditional systems of government and security.

\section{Conflicts of Interest}

The authors declare no conflicts of interest regarding the publication of this paper.

\section{References}

[1] Brubaker, R. (2010) Migration, Membership and the Modern Nation-State: Internal and External Dimensions of the Politics of Belonging. The Journal of Interdisciplinary History, 41, 61-78. https://doi.org/10.1162/jinh.2010.41.1.61

[2] Anderson, B. (2006) Imagined Communities. Verso Press, New York.

[3] Giddens, A. (1990) The Consequence of Modernity. Polity Press, Cambridge.

[4] Hassan, D. (2006) Rise of the Territorial State and the Treaty of Westphalia. Year- 
book of New Zealand Jurisprudence, 9, 62-70.

[5] Hobsbawn, E.J. (1990) Nations and Nationalism since 1780: Program, Myth, Reality. Cambridge University Press, Cambridge.

[6] Yoo, J. (2011) Fixing Failed States. California Law Review, 99, 95-150. https://doi.org/10.2139/ssrn.1552395

[7] Steinberger, H. (1987) Sovereignty. In: Encyclopedia of Disputes Installment 10, Elsevier, Amsterdam, 397-418. https://doi.org/10.1016/B978-0-444-86241-9.50103-2

[8] Geping, N. (2008) An Exploration of the Concept of the Modern Nation-State: The Case of China. Core Ethics, 4, 237-250.

[9] Creveld, M. (1999) The Rise and Decline of the State. Cambridge University Press, Cambridge.

[10] Jackson, J. (2003) Sovereignty-Modern: A New Approach to an Outdated Concept. American Journal of International Law, 97, 782-802. https://doi.org/10.2307/3133680

[11] Brubaker, R. (2010) Migration, Membership, and the Modern Nation-State: Internal and External Dimensions of the Politics of Belonging. Journal of Interdisciplinary History, 41, 61-78. https://doi.org/10.1162/jinh.2010.41.1.61

[12] Stoessinger, J. (1991) The Anatomy of the Nation-State and the Nature of Power. In: Little, R. and Smith, M., Eds., Perspectives on World Politics, Routledge, London, 23-35.

[13] Wimmer, A. and Fenstein, Y. (2014) The Rise of Nation-States across the World. American Sociology Review, 1, 764-790.

[14] Martin, D. (2006) Global Forces and State Restructuring: Dynamics of State Formation and Collapse. Macmillan Palgrave, London.

[15] Lamphear, J. (1976) The Traditional History of the Jie of Uganda. Clarendon Press, Oxford.

[16] Kenya-Uganda Boundary (1973) International Boundaries Study No. 1539, United States of America.

[17] The Uganda Order in the Council (1902) Uganda Official Gazette. Vol. 7, No. 10.

[18] The Sudan-Uganda Boundary (1970) International Boundary Study No. 104, United States of America.

[19] Kwamusi, G. (1996) A History of Border Relations between the People of Uganda and Kenya. The Case of the Abasamia of the Two Countries. MA Thesis, Makerere University, Department of History, Kampala.

[20] Barber, J. (1968) Imperial Frontier: A Study of Relations between the British and the Pastoral Tribes of North Eastern Uganda. East African Publishing House, Nairobi.

[21] Order in the Council Annexing to His Majesty's Dominion and Including in Kenya Colony Certain Territories of Uganda Protectorate (1926) British Foreign State Papers. Vol. 123, Part 1.

[22] Ndenda, M. and Ogalo, A. (2016) Boundary Establishment and Its Influence on Pastoral Resource Conflict between the Pokot and Karamojong since 1902. International Journal of Social Science and Technology, 1, 93-108.

[23] Berman, B. (1990) Crisis and Control in Colonial Kenya. Heinemann Publishers, Nairobi.

[24] Mburu, N. (2001) Firearms and Political Power: The Military Decline of the Turkana of Kenya 1900-2000. Nordic Journal of African Studies, 10, 148-162. 
[25] Lamphear, J. (1976) Aspects of Turkana Leadership during the Era of Primary Resistance. Journal of African History, 17, 225-243. https://doi.org/10.1017/S0021853700001304

[26] Amutabi, M. (2010) Land and Conflict in the Elemi Triangle. Kenya Studies Review, 1, 20-36.

[27] Barber, J.P. (1964) Karamoja in 1910. Uganda Journal, 28, 15-23.

[28] Michael, Q. (1999) A Bibliography of Karamoja, Uganda. Electronic Journal of African Bibliography, 5, 1.

[29] Barber, J.P. (1962) The Karamojong District of Uganda: Pastoral People under Colonial Rule. Journal of African History, 3, 114-115. https://doi.org/10.1017/S0021853700002760

[30] Cisternio, M. (1979) Karamoja the Human Zoo: The History of Planning for Karamoja with Some Tentative Counterplanning. Postgraduate Diploma Dissertation. University College of Swansea, Swansea.

[31] Barber, P. (2018) Development and Pastoral People of Karamoja, North-Eastern Uganda: An Example of Treatment of Symptoms. In: Pastoralism in Tropical Africa, Routledge, Abingdon-on-Thames, 187-205.

[32] Matete, G. and Shumba, C. (2015) Market-Driven Value Chain for the Livestock Sector: Turkana County Report.

[33] Ekaum, D. (2009) Livestock Identification, Traceability and Tracking: Its Role in Enhancing Human Security, Disease Control and Livestock Marketing in IGAD Region. CEWARN, Addis Ababa.

[34] The United Nations (2007) The Report of the United Nations High Commissioner for Human Rights on the Situation of Human Rights in Uganda.

[35] The Republic of Kenya (2006) National Policy on Peace Building and Conflict Management.

[36] Safeworld (2010) Karamoja Conflict and Security Assessment Report.

[37] Quam, M. (1997) Creating Peace in an Armed Society: Karamoja, Uganda. African Studies Quarterly, 1, 33-46.

[38] Daily Nation, February 25, 2017.

[39] International Monetary Fund (2003) Uganda Poverty Reduction Strategy Paper Annual Progress Report. https://doi.org/10.5089/9781451838732.002

[40] The United Nations Commissioner for Human Rights (2007) Report on the Situation of Human Rights in Uganda, August 2007.

[41] New Vision, Saturday September 282013.

[42] Leff, J. (2009) Pastoralists at War: Violence and Insecurity in the Kenya Uganda Sudan Border Region. International Journal of Conflict and Violence, 3, 188-203.

[43] Ndung'u, J. (2010) Analysis of Disarmament Approaches in Kenya and How to Make Them Effective. RECSA Practical Disarmament Validation Workshop, Mombasa, 30-31 August 2010.

[44] The New Vision, Uganda, February 15, 2010.

[45] IKV PAX Christi (2011) Human Security in the Borderlands of Sudan, Uganda and Kenya. http://www.ikvpaxchristi.nl/uk

[46] Lamphear, J. (1994) The Evolution of Ateker "New Model" Armies: Jie and Turkana. In: Fukui, K. and Markakis, J., Eds., Ethnicity and Conflict in the Horn of Africa. James Currey, London, 63-94. 